\title{
Kadar hemoglobin awal sebagai faktor prognostik penderita limfoma non-hodgkin (LNH) yang menjalani kemoterapi
}

\author{
Daniel Winarto', Ni Made Renny A Rena², Wayan Losen Adnyana², Tjokorda Gede Dharmayuda², \\ Ketut Suega², I Made Bakta²
}

\footnotetext{
${ }^{1}$ Program Studi Pendidikan Dokter Spesialis Penyakit Dalam, Fakultas Kedokteran Universitas Udayana / RSUP Sanglah, Denpasar, Bali, Indonesia. ${ }^{2}$ Departemen/ KSM Penyakit Dalam, Fakultas Kedokteran Universitas Udayana/ RSUP Sanglah, Denpasar, Bali, Indonesia.

dr.daniel.winarto@hotmail.com
}

Tanggal diterima : 28 September 2018 Tanggal Disetujui : 25 Oktober 2018 Tanggal Diterbitkan : 2 Nopember 2018
Latar belakang: Anemia sering ditemukan pada saat diagnosis awal LNH. Anemia dapat terjadi karena beberapa kondisi, seperti perdarahan terkait LNH dengan atau tanpa anemia defisiensi besi, anemia karena penyakit kronik, infiltrasi sel-sel LNH ke sumsum tulang, anemia hemolitik autoimun maupun anemia terkait kemoterapi. Anemia mempengaruhi perjalanan klinis dan kesintasan pasien-pasien LNH.

Tujuan: Penelitian ini bertujuan untuk membuktikan bahwa kadar $\mathrm{Hb}$ awal merupakan faktor prognostik penderita LNH yang menjalani kemoterapi.

Metode: Penelitian ini merupakan penelitian kohort retrospektif mulai bulan Januari 2013 sampai bulan September 2017 pada penderita LNH yang menjalani kemoterapi di RSUP Sanglah Denpasar. Hubungan antara kadar Hb dengan skor R-IPI dianalisis menggunakan uji Mann Whitney. Analisis kesintasan menggunakan metode Kaplan Meier dan Cox Proportional Hazard Mode dengan menggunakan software SPSS.

Hasil: Dari 88 penderita LNH, dieksklusi 31 penderita, sehingga total sampel sebanyak 57 orang. Dengan menggunakan analisis komparatif Mann Whitney didapatkan perbedaan signifikan pada skor R-IPI antara pasien LNH dengan $\mathrm{Hb} \geq 10$ $\mathrm{g} / \mathrm{dl}(\mathrm{md}=1, \mathrm{n}=46)$ dan kadar $\mathrm{Hb}<10 \mathrm{~g} / \mathrm{dl}(\mathrm{md}=3, \mathrm{n}=11)(\mathrm{z}=-2,106 ; \mathrm{p}=0,035 ; \mathrm{d}=0,28)$. Analisis dengan Kaplan Meier, didapatkan penderita dengan kadar $\mathrm{Hb}<10 \mathrm{gram} / \mathrm{dL}$ memiliki kesintasan lebih pendek dibanding penderita dengan kadar $\mathrm{Hb} \geq 10$ gram/dL ( \pm 255 vs \pm 850 hari; $\mathrm{p}=0,002$; IK 95\%) dan dengan analisis Cox Regression didapatkan Hazard ratio sebesar $4.46(p=0,005)$.

Simpulan: Kadar hemoglobin awal dapat digunakan sebagai faktor prognostik mortalitas penderita LNH yang menjalani kemoterapi.

Kata Kunci: Anemia, prognostik, Limfoma non-Hodgkin

Background: Anemia is a condition that often be found when NHL is diagnosed. Anemia is caused by several conditions such as, bleeding related to NHL with or without iron deficiency anemia, anemia caused by chronic disease, NHL infiltration to bone marrow, autoimmune hemolytic anemia or chemotherapy related anemia. Anemia affects clinical course and survival rates in NHL patient.

Objective: This study aims to prove that initial hb level is a prognostic factor in NHL patient who undergone chemotherapy.

Methods: This study is a cohort retrospective study starts from Januari 2013 until September 2017 in NHL patients who undergone chemotheraphy in Sanglah Hospital. Correlation between hb level and R-IPI score was analyzed using mann whitney test. Survival analysis was analyzed using Kaplan Meier and cox proportional hazard mode using SPSS software.

Results: From 88 NHL patients, 31 were excluded from study, so that total sample was 57 patients. Using comparative analysis Mann Whitney, we found significant differences between R-IPI score in NHL patient with Hb levels $\geq 10 \mathrm{~g} / \mathrm{dl}$ ( $m d=1, n=46)$ and $\mathrm{Hb}$ levels $<10 \mathrm{~g} / \mathrm{dl}(\mathrm{md}=3, \mathrm{n}=11)(\mathrm{z}=-2,106 ; \mathrm{p}=0,035 ; \mathrm{d}=0,28)$. Kaplan meier analysis, was found patient with $\mathrm{Hb}$ levels $<10 \mathrm{gram} / \mathrm{dL}$ has shorter survival rates compared to those who has Hb levels $\geq 10 \mathrm{gram} /$ $\mathrm{dL}$ ( \pm 255 vs \pm 850 hari; $p=0,002$; IK 95\%) and using cox regression analysis the hazard ratio was $4.46(p=0,005)$. Conclusion: Initial Hb levels can be used as mortality prognostic factors in NHL patients who undergone chemotheraphy. Keywors Anemia, prognostic, non-Hodgkin Limfoma. 


\section{LATAR BELAKANG}

Limfoma non-Hodgkin (LNH) merupakan suatu kelompok keganasan hematologi heterogen yang melibatkan sel-sel limfosit matur baik sel limfosit $\mathrm{T}$ maupun sel limfosit B. ${ }^{1}$ Limfoma non-Hodgkin adalah keganasan sistem limfoid yang paling sering kita temukan dengan proporsi $62,4 \%$ dari seluruh keganasan limfoid. ${ }^{2}$ Sekitar $90 \%$ pasien akan menderita limfoma sel B dan 10\% akan menderita limfoma sel T. Dari berbagai jenis-jenis LNH berdasarkan klasifikasi WHO 2016, Diffuse Large-B cell Lymphoma (DLBCL) merupakan jenis yang paling sering, menyumbang $28 \%$ - $37 \%$ dari limfoma sel B. ${ }^{3-5}$

Limfoma non-Hodgkin berada dalam posisi ke-7 penyebab keganasan paling sering di Amerika Serikat, dengan peningkatan mencapai 89,5\% sejak 1975 hingga 2010. Secara global, LNH berada dalam peringkat ke-8 sebagai penyebab keganasan tersering pada pria dan peringkat ke-11 pada wanita, berkontribusi sebesar 5,1\% dari semua keganasan dan 2,7\% penyebab kematian dari semua keganasan. ${ }^{6}$

Anemia sering terjadi pada penderita-penderita LNH, dimana Morrow et al. melaporkan insidensi anemia pada LNH sebesar 35,3\%. ${ }^{7}$ Pada studi terbaru mengenai spektrum klinis pada penderita LNH, bahkan anemia dilaporkan sebanyak $90,4 \%{ }^{8}$ Anemia tersebut dapat terkait LNH maupun terkait kemoterapi yang diberikan. Anemia terkait LNH dapat disebabkan oleh pendarahan akut maupun kronis dengan predileksi LNH pada tempat-tempat tertentu seperti saluran cerna (misalnya mucosa-associated lymphoid tissue [MALT] lymphoma saluran cerna), penekanan hematopoiesis akibat infiltrasi sel-sel limfoma, anemia hemolitik autoimun dan anemia akibat inflamasi kronis. Sedangkan anemia terkait kemoterapi, pada umumnya disebabkan karena supresi sumsum tulang akibat obat kemoterapi itu sendiri. Kadar hemoglobin $(\mathrm{Hb})$ awal (baseline) menunjukkan prediktor kegagalan kemoterapi yang signifikan dan kadar $\mathrm{Hb}$ awal yang rendah berhubungan dengan kadar LDH serum yang tinggi serta stadium yang lebih lanjut. ${ }^{7}$ Walaupun tidak termasuk dalam kriteria International prognostic index (IPI), anemia dapat dijadikan sebagai prediktor prognosis yang buruk pada LNH yang agresif terutama untuk terjadinya mortalitas dini. ${ }^{9}$

Faktor prognostik pada LNH dapat dinilai secara klinis maupun secara laboratoris dengan biomarker. Dalam praktis klinis sehari-hari, kita menggunakan faktor prognostik klinis berupa FLIPI (Follicular Lymphoma International Prognostic Index), IPI dan R-IPI (Revised International Prognostic Index). ${ }^{10,11}$ Dari ketiga indeks prognostik tersebut, IPI dan R-IPI yang sering kita gunakan, karena LNH tipe agresif (DLBCL) yang paling sering kita jumpai. Indeks prognostik tersebut (IPI dan R-IPI) terdiri dari 5 kriteria berupa umur, stadium LNH, LDH serum, status performa dan keterlibatan extranodal. Kriteriakriteria tersebut memerlukan pemeriksaan pencitraan yang canggih (Computerized Tomography [CT]-scan, Magnetic Resonance Imaging atau Positron Emission Tomography [PET]scan), pemeriksaan serum laboratorium yang tidak rutin (lactace dehyhidrogenase [LDH]) serta terkadang memerlukan biopsi sumsum tulang. Pada kondisi-kondisi tertentu apabila terdapat hambatan fasilitas pemeriksaan/tindakan penunjang tersebut, maka sulit untuk menentukan faktor prognostik klinis.

Berdasarkan paparan di atas, maka anemia yang sering dijumpai pada penderita LNH yang dapat dideteksi secara klinis maupun dengan pemeriksaan laboratorium yang sederhana (kadar $\mathrm{Hb}$ ) dapat dijadikan sebagai petanda prognostik penderita LNH terutama yang menjalankan kemoterapi. Oleh sebab itu, kami ingin menilai apakah kadar $\mathrm{Hb}<10$ (anemia secara klinis) memiliki prognostik yang lebih buruk dari $\mathrm{Hb}$ $\geq 10 \mathrm{~g} / \mathrm{dl}$ berdasarkan skor R-IPI dan apakah $\mathrm{Hb}<10 \mathrm{~g} / \mathrm{dl}$ memiliki overall survival (OS) yang lebih pendek dibandingkan $\mathrm{Hb} \geq 10 \mathrm{~g} / \mathrm{dl}$ pada penderita-penderita LNH yang menjalani kemoterapi. ${ }^{12}$ Dengan demikian, diharapkan kadar $\mathrm{Hb}$ awal dapat dijadikan sebagai faktor prognostik penderita LNH yang menjalani kemoterapi.

\section{METODE}

Penelitian ini merupakan penelitian kohort retrospektif dengan mengambil data sampel melalui buku register pasien Divisi Hemato-onkologi, Departemen Penyakit Dalam RSUP Sanglah, dari bulan Januari 2014 hingga September 2017. Kriteria inklusi sampel penelitian adalah semua pasien LNH berusia di atas 12 tahun yang menjalani kemoterapi, yang terdaftar di buku register Divisi Hemato-onkologi, sedangkan sampel akan diekslusi apabila tidak memiliki data-data yang lengkap terkait variabel-variabel yang akan dianalasis. Data informasi klinis yang dikumpulkan berupa usia, jenis kelamin, stadium klinis, diagnosis patologi, tanggal diagnosis LNH, tanggal meninggal, jenis kemoterapi, status performa, data laboratorium rutin (darah lengkap, BUN/Sc, SGPT, SGOT), kadar serum LDH. Data-data laboratorium yang digunakan adalah hasil laboratorium awal saat pasien didiagnosis pertama kali (baseline). Data-data tersebut dianalisis secara deskriptif untuk karakteristik sampel. Setelah dilakukan uji normalitas Kolmogorov-Smirnov, maka pengaruh kadar $\mathrm{Hb}(<10$ vs $\geq$ $10 \mathrm{~g} / \mathrm{dl}$ ) terhadap skor R-IPI dianalisis secara komparatif dengan uji Mann Whitney (non parametrik). Overall survival (OS) didefinisikan sebagai waktu sejak awal diagnosis hingga terjadinya kematian oleh sebab apapun. Metode KaplanMeier digunakan untuk analisis kesintasan (survival) dan Cox propotional Hazard mode digunakan untuk perbandingan Hazard Ratio (HR). Semua uji analisis dalam penelitian ini menggunakan software SPSS 23 dengan signifikansi statistik pada nilai $\mathrm{p}<0,05$. 
HASIL

Dari periode bulan Januari 2014 hingga September 2017, didapatkan 88 pasien LNH yang didiagnosis di Divisi Hemato-onkologi, Departemen Ilmu Penyakit Dalam RSUP Sanglah. Dari 88 pasien tersebut, sebanyak 31 pasien dieksklusi karena sebagian tidak menjalani kemoterapi dan sebagian lagi terdapat data-data yang hilang, sehingga total sampel sebanyak 57 pasien.

Dari 57 pasien LNH tersebut, LNH lebih banyak diderita oleh pria sebanyak 54\% (31) kasus. Kisaran umur pasien LNH antara 14 - 88 tahun dengan median 53 tahun, sebagian besar kasus (67\%) kasus berumur < 60 tahun. Pada saat diagnosis, sebanyak 33\% (19) kasus berada pada stadium 2 dengan 63\% (36) kasus memiliki B symptoms dan terrdapat $16 \%$ (9) kasus dengan keterlibatan ekstranodal $\geq 2$. Sebelum menjalani kemoterapi sebagian besar (86\%) pasien dalam status performa yang relatif baik $(\mathrm{ECOG}<2)$. Diagnosis secara patologi anatomi pada 57 pasien LNH tersebut, sesuai urutan dari frekuensi terbanyak, DLBCL (32\%), mixed small \& large B cell lymphoma (25\%), diffuse predominantly large cell B lymphoma (9\%), undetermined (3\%) dan sebanyak 31,6\% (18) kasus tidak terdapat data patologi anatomi. Dari 4 jenis regimen kemoterapi yang diberikan pada 57 pasien tersebut, RCHOP merupakan regimen yang paling banyak diberikan sebesar 63\% (36) kasus.

Dari data-data laboratorium, $\mathrm{Hb}$ terendah sebesar 4 $\mathrm{g} / \mathrm{dl}$ pada saat pertama didiagnosis, rentang $\mathrm{Hb} 4 \mathrm{~g} / \mathrm{dl}-17,7$ g/dl dengan rerata $\mathrm{Hb} 11,5 \mathrm{~g} / \mathrm{dl}$ pada 57 pasien LNH. Jika dikelompokkan berdasarkan titik potong $10 \mathrm{~g} / \mathrm{dl}$, sebagian besar pasien (81\%) dengan kadar $\mathrm{Hb}$ awal $\geq 10$. Kadar LDH berkisar antara 15 - 3834 U/L dengan rerata 704 U/L. Dengan menggunakan batas normal atas LDH sesuai nilai laboratorium RSUP Sanglah (480 U/L), sebanyak 56\% (32) kasus memiliki $\mathrm{LDH}>480 \mathrm{U} / \mathrm{L}$.

Berdasarkan indeks prognostik R-IPI, sebanyak 46\% (26) kasus memiliki prognosis yang baik, 30\% (17) kasus dengan prognosis buruk dan 24\% (14) kasus dengan prognosis sangat baik. Ringkasan lebih detail mengenai karakteristik seluruh pasien dapat dilihat pada Tabel 1.

Uji Mann-Whitney menunjukkan bahwa terdapat perbedaan signifikan pada skor prognostik R-IPI antara pasien LNH dengan kadar $\mathrm{Hb} \geq 10 \mathrm{~g} / \mathrm{dl}$ (median =1, $\mathrm{n}=46$ ) dan kadar $\mathrm{Hb}<10$ (median=3, $\mathrm{n}=11$ ) dengan nilai $\mathrm{z}=-2,106 ; \mathrm{p}=0,035 ;$ $\mathrm{d}=0,28$. Nilai $d$ menunjukan ukuran efek yang sedang $(\mathrm{r}>2)$ berdasarkan kriteria Cohen 1988.

Pada Tabel 2, analisis Kaplan-Meier menunjukkan bahwa rerata waktu survival pada 11 pasien dalam kelompok $\mathrm{Hb}<10 \mathrm{~g} / \mathrm{dl}$ sebesar 255 hari sedangkan pada 46 pasien dalam kelompok $\mathrm{Hb} \geq 10 \mathrm{~g} / \mathrm{dl}$ sebesar 850 hari. Perbedaan rerata waktu survival kedua kelompok tersebut signifikan secara statistik dengan uji Log Rank ( $=0,002)$.
Tabel 1. Karakteristik pasien

\begin{tabular}{|c|c|}
\hline Karakteristik & Jumlah (\%) \\
\hline Jumlah total pasien & 57 \\
\hline \multicolumn{2}{|l|}{ Jenis Kelamin } \\
\hline Laki-laki & $31(54 \%)$ \\
\hline Perempuan & $26(46 \%)$ \\
\hline \multicolumn{2}{|l|}{ Umur (tahun) } \\
\hline Rentang & $14-88$ \\
\hline Median & 53 \\
\hline$<60 / \geq 60$ & $11(19 \%) / 46(81 \%)$ \\
\hline \multicolumn{2}{|l|}{ Stadium Klinis } \\
\hline I & $11(19 \%)$ \\
\hline II & $19(33 \%)$ \\
\hline III & $15(27 \%)$ \\
\hline IV & $12(21 \%)$ \\
\hline Simptom B & $36(63 \%)$ \\
\hline Jumlah extranodal >1 & $9(16 \%)$ \\
\hline \multicolumn{2}{|l|}{ Status performa (ECOG) } \\
\hline$<2$ & $49(86 \%)$ \\
\hline$\geq 2$ & $8(14 \%)$ \\
\hline \multicolumn{2}{|l|}{ Histologis LNH } \\
\hline DLBCL & $18(31 \%)$ \\
\hline Diffuse predominantly LCBL & $5(9 \%)$ \\
\hline Mixed type & $14(25 \%)$ \\
\hline Undetermined & $2(3 \%)$ \\
\hline No data & $18(32 \%)$ \\
\hline \multicolumn{2}{|l|}{ Kemoterapi } \\
\hline R-CHOP & $36(63 \%)$ \\
\hline $\mathrm{CHOP}$ & $19(33 \%)$ \\
\hline RICE & $1(2 \%)$ \\
\hline R-ESHAP & $1(2 \%)$ \\
\hline \multicolumn{2}{|l|}{ Hemoglobin $(\mathrm{g} / \mathrm{dl})$} \\
\hline Rentang & $4,06-17,17$ \\
\hline Rerata & 11,6 \\
\hline $\mathrm{Hb}<10$ & $11(19 \%)$ \\
\hline $\mathrm{Hb} \geq 10$ & $46(81 \%)$ \\
\hline \multicolumn{2}{|l|}{ LDH serum (U/L) } \\
\hline Rentang & $15-3834$ \\
\hline Rerata & 704 \\
\hline LDH tinggi $(>480)$ & $32(56 \%)$ \\
\hline \multicolumn{2}{|l|}{ Status terakhir } \\
\hline Hidup & $25(44 \%)$ \\
\hline Meninggal & $32(56 \%)$ \\
\hline \multicolumn{2}{|l|}{ Indeks Prognostik (R-IPI) } \\
\hline Very good & $14(24 \%)$ \\
\hline Good & $26(46 \%)$ \\
\hline Poor & $17(30 \%)$ \\
\hline
\end{tabular}

ECOG=Eastern Cooperative Oncology Group, DLBCL=diffuse large $B$ cell lymphoma, R-CHOP=rituximab-cyclophosphamid doxorubicin vincristine prednisone, $\mathrm{R}-\mathrm{ICE}=$ rituximab-ifosfamide carboplatin etoposide, R-ESHAP=rituximab-etoposide cytarabine cisplatinum methylprednisolone, $\quad \mathrm{LDH}=$ lactase dehydrogenase, $\mathrm{R}-\mathrm{IPI}=$ revised International Prognostic index. 
Tabel 2. Karakteristik survival pada sampel penelitian

\begin{tabular}{lcccc}
\hline Kelompok pasien & Jumlah Pasien & $\begin{array}{c}\text { Jumlah } \\
\text { kematian } \\
\text { (events) }\end{array}$ & $\begin{array}{c}\text { Jumlah sensor } \\
\text { (\%) }\end{array}$ & $\begin{array}{c}\text { Rerata waktu survival dalam } \\
\text { hari (IK 95\%) }\end{array}$ \\
\hline $\mathrm{Hb}<10 \mathrm{~g} / \mathrm{dl}$ & 11 & 6 & $5(45,5 \%)$ & $255(114-396)$ \\
\hline $\mathrm{Hb} \geq 10 \mathrm{~g} / \mathrm{dl}$ & 46 & 10 & $36(78,3 \%)$ & $850(687-1013)$ \\
\hline
\end{tabular}

Log Rank (Mantel-Cox) sig. 0,002

IK=indeks kepercayaan

Pada kurva Kaplan Meier (Gambar 1), tampak perbandingan overall survival antara kelompok $\mathrm{Hb}<10 \mathrm{~g} / \mathrm{dl}$ dan $\mathrm{Hb} \geq 10 \mathrm{~g} / \mathrm{dl}$, dimana pasien $\mathrm{LNH}$ dengan kadar $\mathrm{Hb} \geq$ $10 \mathrm{~g} / \mathrm{dl}$ memiliki waktu survival yang lebih baik (kurva hijau) dibandingkan dengan pasien LNH dengan $\mathrm{Hb}<10 \mathrm{~g} / \mathrm{dl}$ (kurva biru). Kemudian dengan menggunakan analisis model Cox Regression didapatkan hazard ratio (HR) 4,46 ( $\mathrm{p}=0,005)$.

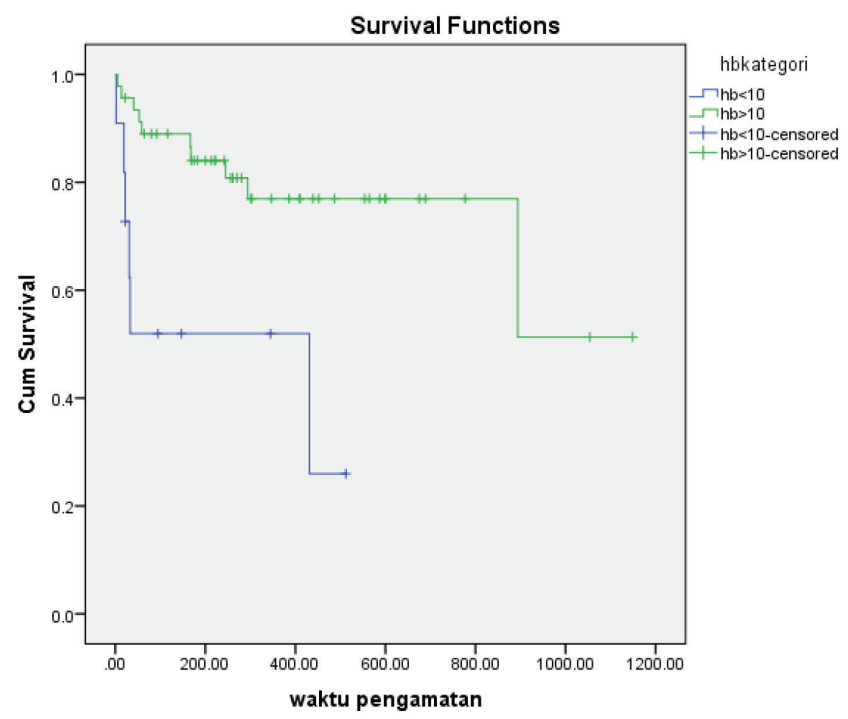

Gambar 1. Kurva survival Kaplan-Meier berdasarkan kategori kadar $\mathrm{Hb}(<10 \mathrm{~g} / \mathrm{dl}$ vs $\geq 10 \mathrm{~g} / \mathrm{dl})$. Waktu pengamatan dalam hari.

\section{DISKUSI}

Studi multisenter nasional, yang telah dipublikasi tahun 2015, memiliki banyak kesamaan karakteristik pasien dengan pasien yang ada pada penelitian ini. ${ }^{13}$ Pada studi yang melibatkan 13 pusat hematologi tersebut, melaporkan median umur pasien LNH adalah 51 tahun dengan proporsi pria lebih banyak (55,5\%), kebanyakan pada saat diagnosis berada pada stadium II $(35,4 \%)$ dengan sebagian besar memiliki status performa ECOG < 2 (77,7\%). Mereka juga melaporkan histologis terbanyak adalah DLBCL dengan keterlibatan ekstranodal < 2 sebesar 100\% kasus dan sebagian besar dengan skor IPI 2 (36\%) serta kadar LDH yang meningkat sebesar 70\% kasus. Pada penelitian ini median umur pasien LNH adalah 53, dengan pria lebih banyak (54\%), kebanyakan juga didiagnosis pada stadium II (33\%) dengan status performa ECOG < 2 (86\%). Histologis terbanyak dalam penelitian ini DLBCL dengan mayoritas keterlibatan ektranodal < 2 sebanyak $86 \%$. Selain itu, proporsi terbanyak indeks R-IPI penelitian ini adalah good (46\%), yang berada dalam rentang nilai $1-2$, yang bila dikonversi ke indeks IPI adalah kebanyakan low risk \& low intermediate risk, sama seperti studi multisenter nasional di atas. Dengan demikian, karakteristik pasien di RSUP Sanglah pada penelitian ini hampir sama dengan karakteristik nasional.

Pada studi ini, kami menggunakan titik potong kadar $\mathrm{Hb} 10 \mathrm{~g} / \mathrm{dl}$, anemia secara klinis yang dipakai pada pusat pendidikan kami. ${ }^{12}$ Insidensi anemia klinis $(\mathrm{Hb}<10 \mathrm{~g} / \mathrm{dl})$ pasien LNH pada studi ini hanya 19\%, lebih kecil dari studistudi lain dengan kisaran 49\% - 100\% ${ }^{8,14-18} \mathrm{Hal}$ ini disebabkan karena pada studi-studi lain, sebagian besar menggunakan titik potong anemia sesuai kriteria WHO (pria < $13 \mathrm{~g} / \mathrm{dl}$; wanita $<12 \mathrm{~g} / \mathrm{dl}$ ).

Banyak mekanisme yang berkontribusi terhadap terjadinya anemia pada pasien LNH, baik terkait LNH maupun terkait kemoterapi. Mekanisme anemia yang terkait dengan LNH seperti infiltrasi sumsum tulang, kondisi inflamasi kronis, pendarahan baik akut maupun kronis, defisiensi nutrisional dan anemia hemolitik autoimun. Anemia yang disebabkan oleh infiltrartif sumsum tulang memiliki prognosis yang jelek. ${ }^{14}$ Studi-studi lain menunjukkan bahwa anemia berkaitan dengan prognosis yang lebih jelek dan peningkatan mortalitas. ${ }^{19-20}$ Pada pasien LNH, terutama DLBCL, didapatkan kadar serum interleukin-6 yang tinggi, berkorelasi dengan peningkatan kadar serum hepsidin dan berkorelasi terbalik dengan kadar eritropoetin, yang berkontribusi untuk terjadinya anemia akibat penyakit kronik. ${ }^{21}$ Anemia itu sendiri juga menyebabkan penurunan kapasitas fungsional dan kualitas hidup. ${ }^{22-23}$ Stres tambahan terhadap sumsum tulang dan efek toksik pada ginjal oleh kemoterapi memperburuk anemia pada pasien dengan LNH. ${ }^{24} \mathrm{Hal}$ ini tampak jelas bahwa kadar $\mathrm{Hb}$ sangat penting dalam memprediksi prognosis pasien-pasien dengan LNH 
baik dengan ataupun tanpa kemoterapi.

Pada penelitian ini kami dapat menunjukkan bahwa pasien LNH dengan kadar $\mathrm{Hb} \geq 10 \mathrm{~g} / \mathrm{dl}$ memiliki prognostik yang lebih baik dari pasien LNH dengan kadar $\mathrm{Hb}<10 \mathrm{~g} /$ dl. Hal ini berdasarkan analisis komparatif dengan uji MannWhitney yang secara statistik signifikan. Pada kelompok pasien LNH dengan kadar $\mathrm{Hb} \geq 10 \mathrm{~g} / \mathrm{dl}$ (median $=1, \mathrm{n}=46$ ), terdapat 46 orang dengan median skor R-IPI 1, yang berarti sebanyak 46 pasien dengan kadar $\mathrm{Hb} \geq 10 \mathrm{~g} / \mathrm{dl}$ mempunyai prognosis baik. Pada kelompok dengan kadar $\mathrm{Hb}<10 \mathrm{~g} / \mathrm{dl}$ (median=3, $\mathrm{n}=11$ ), terdapat 11 pasien dengan median skor R-IPI 3, yang berarti 11 pasien LNH tersebut mempunyai prognosis yang buruk. Perbedaan antara kedua kelompok tersebut memiliki kekuatan sedang berdasarkan nilai ukuran efek (size effect) d sebesar 0,28.

Pada kurva Kaplan-Meier, tampak bahwa kelompok pasien $\mathrm{LNH}$ dengan $\mathrm{Hb} \geq 10 \mathrm{~g} / \mathrm{dl}$ memiliki waktu survival yang lebih baik dibandingkan dengan kelompok pasien dengan $\mathrm{Hb}$ $<10 \mathrm{~g} / \mathrm{dl}$. Hasil analisis Cox regression dengan HR sebesar 4,46, mengestimasi bahwa pasien LNH dengan $\mathrm{Hb}<10 \mathrm{~g} / \mathrm{dl}$ memiliki kemungkinan resiko mortalitas sebesar hampir 4,5 kali dibandingkan dengan pasien $\mathrm{LNH}$ dengan kadar $\mathrm{Hb} \geq 10$ $\mathrm{g} / \mathrm{dl}$.

Hasil yang didapatkan dari penelitian ini menunjukkan bahwa kadar $\mathrm{Hb}$, terutama $\mathrm{Hb}<10 \mathrm{~g} / \mathrm{dl}$ merupakan faktor prediktor mortalitas pada pasien-pasien LNH yang menjalani kemoterapi. Hasil penelitian ini sesuai dengan penelitian sebelumya, yang menunjukkan bahwa LNH tipe agresif merupakan prediktor prognosis buruk dengan tingkat mortalitas dini yang tinggi. ${ }^{9}$ Pada studi retrospektif oleh Moullet et al. menunjukkan hal yang sama, dimana anemia (hb <12 g/dl) merupakan faktor prognostik yang buruk terhadap overall survival dan progression-free survival serta menunjukkan bahwa insidensi anemia lebih tinggi apabila terdapat keterlibatan sumsum tulang. ${ }^{18}$ Pada studi-studi lain, anemia sebagai faktor prognostik pada pasien-pasien LNH dipengaruhi oleh jenis LNH dimana pada LNH tipe indolen (Follicular Lymphoma), anemia tidak dapat dijadikan sebagai faktor prognostik. ${ }^{25-26}$

Pada penelitian ini terdapat kekurangan-kekurangan di antaranya, kami tidak melakukan analisis efek kemoterapi pada kadar $\mathrm{Hb}$ dan pengaruhnya terhadap survival dan kami tidak mempertimbangkan pengaruh jenis-jenis LNH terhadap kadar Hb. Kami juga tidak dapat menentukan etiologi anemia dari masing-masing pasien yang kemungkinan dapat mempengaruhi hasil penelitian ini. Dan yang terakhir, kami tidak dapat menentukan sebab kematian yang mungkin dapat mempengaruhi survival pasien. Semua kekurangan tersebut dikarenakan penelitian ini bersifat retrospektif yang memiliki hambatan dalam pengambilan data-data lain yang terkait dan evaluasi lebih lanjut kondisi klinis pasien.
Sepertinya temuan anemia, terutama kadar $\mathrm{Hb}<10 \mathrm{~g} /$ dl, pada saat diagnosis awal LNH, perlu mendapat perhatian khusus dan dikaji lebih dalam mengenai etiologi anemianya serta pengaruhnya untuk outcome yang lebih baik.

\section{SIMPULAN}

Hasil penelitian ini menunjukkan bahwa pasien LNH dengan kadar $\mathrm{Hb}$ awal $<10 \mathrm{~g} / \mathrm{dl}$ memiliki prognostik lebih buruk berdasarkan R-IPI. Pasien LNH dengan kadar $\mathrm{Hb}<10 \mathrm{~g} / \mathrm{dl}$ memiliki resiko mortalitas hingga 4,5 kali dibandingkan $\mathrm{Hb} \geq 10 \mathrm{~g} / \mathrm{dl}$. Dengan demikian, kadar $\mathrm{Hb}$ awal dapat digunakan sebagai faktor prediktor mortalitas pasienpasien LNH yang menjalani kemoterapi.

\section{DAFTAR PUSTAKA}

1. McKinney MS, Dave SS. Origin of Non-Hodgkin Lymphoma In: Hoffman R, Benz EJ, Silberstein LE, Heslop H, Weitz J, Anastasi $\mathrm{J}$, editors. Hematology Basic Principles and Practice. $6^{\text {th }}$ edition. Philadelphia: Elsevier Saunders; 2013. p. 1157-58.

2. Longo DL. Malignancies of Lymphoid Cells In: Longo DL, Fauci AS, Kasper DL, Hauser SL, Jameson JR, Loscalzo J, editors. Harrison's principle of internal medicine. $19^{\text {th }}$ edition. New York: McGraw-Hill; 2015. p. 695-96.

3. Armitage JO, Weisenburger DW. New approach to classifying nonHodgkin's lymphomas: clinical features of the major histologic subtypes. Non-Hodgkin's Lymphoma Classification Project. J Clin Oncol. 1998; 16: 2780-95.

4. Morton LM, Wang SS, Devesa SS, dkk. Lymphoma incidence patterns by WHO subtype in the United States, 1992-2001. Blood. 2006; 107: $265-76$.

5. Swerdlow SH, Campo E, Pileri SA, dkk. The revision of the WHO classification of lymphoid neoplasms. Blood. 2016; 127: 2375-90.

6. Boffetta P. Epidemiology of adult non-Hodgkin lymphoma. Ann Oncol. 2011; 22: iv27-iv31.

7. Morrow TJ, Volpe S, Gupta S, dkk. Anemia of cancer in intermediategrade non-Hodgkin's lymphoma. South Med J. 2002; 95: 889 - 96.

8. Neeravari VS; Bannigidad D. Clinical Spectrum of non-Hodgkin Lymphoma: A Hospital Based Study of 410 cases. AABS. 2016; 3(1): A88-A93.

9. Dumontet C, Mounier N, Munck JN, dkk. Factors predictive of early death in patients receiving high-dose CHOP (ACVB regimen) for aggressive non-Hodgkin's lymphoma: a GELA study. Br J Haematol. 2002; 118: 210 - 17

10. Solal-Celigny P, Roy P, Colombat P, dkk. Follicular Lymphoma International Prognostic Index. Blood. 2004; 104: 1258-65.

11. Sehn LH, Berry B, Chhanabhai M, dkk. The revised International Prognostic Index (R-IPI) is a better predictor outcome than the standard IPI for patients with diffuse large B-cell lymphoma treated with R-CHOP. Blood. 2007; 109: 1857-61.

12. Bakta IM. Sistem Eritroid. Dalam: Bakta IM, penyunting. Hematologi Klinik Ringkas. Jakarta: EGC; 2006. Hal 12.

13. Reksodiputro AH. Multicentre epidemiology and survival study of B-Cell non-Hogkin lymphoma patients in Indonesia. J Blood Disorders Transf. 2015; 6(2).

14. Hingorjo MR, Sadiqa S. Presentation, staging and diagnosis of lymphoma: a clinical perspective. J Ayub Med Coll Abbottabad. 2008; 20(4): 100-3

15. Hassan K, Ikram N, Bukhari KP, dkk. The pattern of Bone Marrow Infiltration in Non-Hodgkins Lymphomas. Journal of Pakistan Medical Association. 1995; 45:173-6

16. Conlan MG, Armitage JO, Bast BSM, dkk. Clinical significance of hematologic parameters in non-Hodgkins lymphoma at diagnosis. 
Cancer. 1991; 67: $1389-95$.

17. Ghosh J, Singh RKB, Saxena R, dkk. Prevalence and aetiology of anaemia in lymphoid malignancies. TNMJI. 2013; 26 (2): 79-81.

18. Idris M, Shah SH, Fareed J, dkk. An experience with sixty cases of haematological malignancies; a clinicohaematological correlation. $J$ Ayub Med Coll Abbottabad. 2004; 16: 51-4.

19. Moullet I, Salles G, Ketterer N, dkk. Frequency and significance of anemia in non-Hodgkin's lymphoma patients. Ann Oncol. 1998; 9:110915.

20. Hasenclever D, Diehl V. A prognostic score for advanced Hodgkin's Disease. International Prognostic Factors Project on Advanced Hodgkin's Disease. N Engl J Med. 1998; 339: 1506-14.

21. Tisi MC, Bozzoli V, Giachelia M, dkk. Anemia in diffuse large B-cell non-Hodgkin lymphoma: the role of interleukin-6, hepcidin and erythropoietin. Leukemia lymphoma. 2014; 55(2): 270-5.

22. Ludwig H, Strasser K. Symptomatology of anemia. Semin Oncol. 2001; 28(2-8): 7-14
23. Cella D. Factors influencing quality of life in cancer patients: Anemia and fatigue. Semin Oncol. 1998; 25(3-7): 43-6.

24. Groopman JE, Itri LM. Chemotherapy-induced anemia in adults: incidence and treatment. J Natl Cancer Inst. 1999; 91: 1616-34.

25. Federico M, Vitolo U, Zinzani PL, dkk. Prognosis of follicular lymphoma: a predictive model based on a retrospective analysis of 987 cases. Intergruppo Italiano Linformi. Blood. 2000; 95: 783-89.

26. Callea V, Clo V, Morabito F, dkk. Retrospective analysis of mantle cell lymphoma: experience of the "Gruppo Italiano per lo Studio dei Linfomi” (GISL). Haematologica. 1998; 83: 993-7.

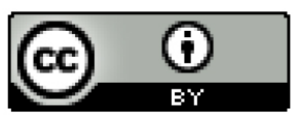

This work is licensed under a Creative Commons Attribution 4.0 International License. 